\title{
Use of $\beta$-caryophyllene to combat bacterial dental plaque formation in dogs
}

\author{
Fábio Alessandro Pieri ${ }^{1,2}$, Marina Campos de Castro Souza ${ }^{2}$, Ligia Lobato Ramos Vermelho², \\ Marina Lobato Ramos Vermelho², Pedro Griffo Perciano², Fabiano Souza Vargas ${ }^{3}$, Andréa Pacheco Batista Borges ${ }^{2}$, \\ Valdir Florêncio da Veiga-Junior ${ }^{3}$ and Maria Aparecida Scatamburlo Moreira ${ }^{2^{*}}$
}

\begin{abstract}
Background: Periodontal disease is a highly prevalent illness that affects many dogs, reaching up to $85 \%$ prevalence in individuals over the age of 4 years. Currently the drug of choice for combating the formation of dental plaque in these animals, the etiologic agent of the disease, is chlorhexidine, which has several side effects reported. Thus, surveys are conducted throughout the world in order to identify potential substitutes for antimicrobial therapy and prevention of periodontal disease. The objective of the work was to evaluate the antimicrobial activity of $\beta$-caryophyllene against bacteria from dog's dental plaque in vitro and in vivo. The minimum inhibitory concentration was evaluated by agar microdilution assay, the induction or inhibition of bacterial adherence by sub-inhibitory concentrations in 96-well plates, and reduction of dental plaque formation in mongrel dogs subjected to topical solution with $\beta$-caryophyllene for 15 days.
\end{abstract}

Results: Results showed minimum inhibitory concentrations above $100 \mathrm{mg} / \mathrm{mL}$ for $25 \%$ of the isolates, $100 \mathrm{mg} / \mathrm{mL}$ for $3 \%, 50 \mathrm{mg} / \mathrm{mL}$ for $25 \%, 25 \mathrm{mg} / \mathrm{mL}$ for $12 \%, 12.5 \mathrm{mg} / \mathrm{mL}$ for $19 \%$ and $6.25 \mathrm{mg} / \mathrm{mL}$ for $16 \%$. Bacterial adherences of three Enterococcus sp., one Streptococcus sp., one Haemophilus sp., one Aerococcus sp., one Bacillus sp. and one Lactococcus sp. isolates were inhibited by subinhibitory concentration. One Lactococcus sp., one Bacillus sp. and one Streptococcus sp. were stimulated to adhere by concentrations of $0.19,1.56$ and $0.78 \mathrm{mg} / \mathrm{mL}$, respectively. In vivo assay showed reduction in dental plaque formation by $\beta$-caryophyllene, with final plaque coverage of $23.3 \pm 2.6 \%$ of the total area of the teeth, with significant difference compared with chlorhexidine group $(37.5 \pm 3.7 \%-p<0.05)$ and negative control group $(65.5 \pm 2.5 \%-p<0.001)$.

Conclusions: The results showed that $\beta$-caryophyllene has antimicrobial activity against the proliferation of dog's dental plaque-forming bacteria representing a suitable alternative to the use of chlorhexidine in prophylaxis and treatment of periodontal disease of dogs.

Keywords: Antimicrobial, Dogs, Dental plaque, Adhesion, Natural phytochemical

\section{Background}

Periodontal disease is a highly prevalent illness that affects many dogs, reaching up to $85 \%$ prevalence in individuals over the age of 4 years [1]. It affects the supporting and protective structures of the teeth and its aetiological agent is the bacterial plaque that develops on the tooth surface, and the immune reaction to infection [2]. Tooth brushing is the most suitable procedure

\footnotetext{
* Correspondence: masm@ufv.br

2Departamento de Veterinária, Universidade Federal de Viçosa, Av. P.H. Rolfs, s/n, Câmpus UFV, CEP: 36570-000 Viçosa, Minas Gerais, Brasil

Full list of author information is available at the end of the article
}

for the prevention of periodontal disease through mechanical removal of dental plaque; however, some alternatives can be employed simultaneously to brushing with the intention of increasing the efficiency of plaque removal. Among these alternatives is the administration of antibacterial substances, which, by preventing the proliferation or adhesion of bacteria to the teeth surface, inhibit the development of periodontal disease [3].

In addition, there is evidence that biofilm formation can be stimulated by certain antimicrobials in subinhibitory concentrations, which makes it necessary to investigate a potential stimulus for bacterial adherence 
by antimicrobial agents, making its use in therapy impossible $[4,5]$. Studies have indicated several classes of antibiotics, including tetracyclines, quinopristina-dalfopristin, erythromycin and enrofloxacin, which stimulate the formation of biofilms by Staphylococcus epidermidis and Escherichia coli $[5,6]$. In contrast, the discovery of therapeutic agents that are capable of inhibiting biofilm formation, even in sub-inhibitory concentrations, would be useful for the prevention of periodontal disease by inhibiting the formation of dental plaque [3].

Chlorhexidine is currently the drug of choice for combating dental plaque bacteria, and is usually commercialised at the concentration of $0.12 \%$ [7]. However, the use of this drug has some side effects, such as darkening of the tooth enamel, loss of taste, burning sensation in the oral cavity and ulceration of the oral mucosa, as well as a bitter taste and the fact that it enables the emergence of resistant bacteria [8]. Therefore, there is a need to search for alternatives to this drug for prophylaxis and treatment of periodontal disease [9].

The $\beta$-caryophyllene is a sesquiterpene $\left(\mathrm{C}_{15} \mathrm{H}_{24}-\right.$ Fig. 1$)$, identified in the CAS (Chemical Abstract Service) under number 87-44-5; this is found in many plant sources, and shows great potential [10]. Studies have shown low toxicity and high applicability, with this substance being used for several purposes, including local anaesthesia [11], antiinflammatory action [12, 13], antispasmodic action [14], antimicrobial activity [15], anxiolytic [16], and protection against ischemic injury in neurons [17], among others.

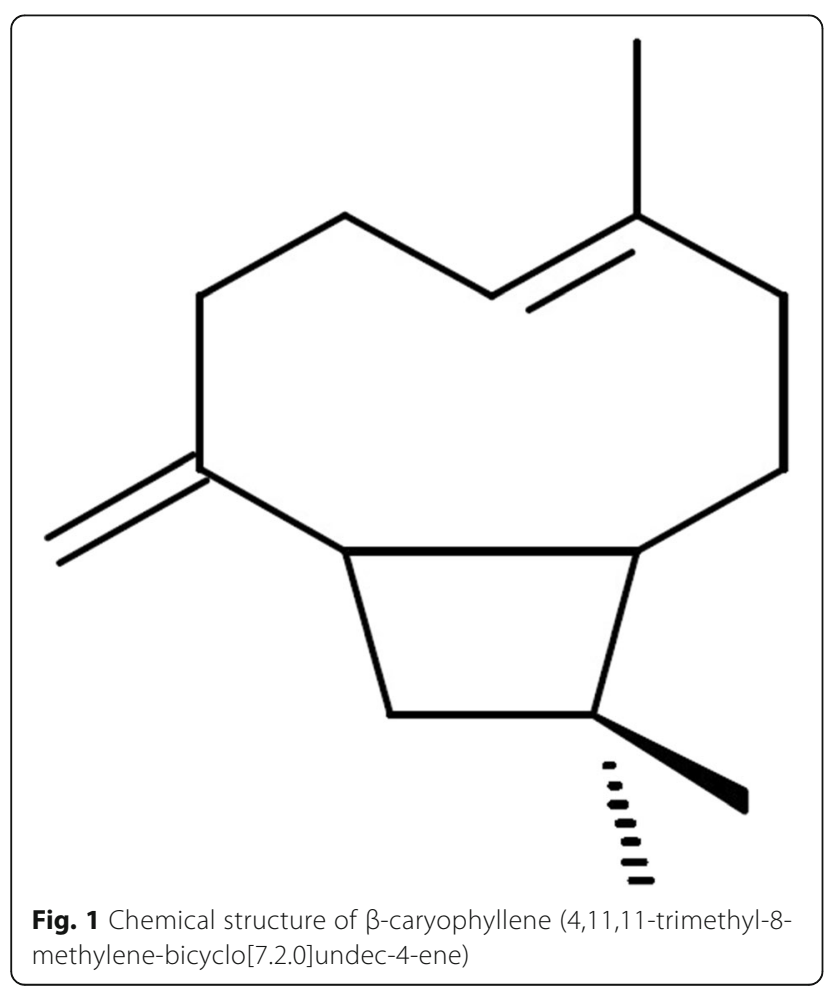

Several studies to identify antimicrobial activity have been conducted with plants that have high percentages of $\beta$ caryophyllene in their composition, presenting positive results for these extracts against several pathogens: Thymus kotschyanus [18], Spiranthera odoratissima [19], Lantana sp. [20], Vernonia remotiflorae V. brasiliana [21], Syzygium cumini [22], and Lippia gracillis [23], among others.

Considering the high prevalence of periodontal disease in dogs, the side effects caused by the drug of choice currently to combat microorganisms of dental plaque, and the described antimicrobial potential of $\beta$-caryophyllene, the aim of this work was to evaluate the antimicrobial activity of this phytochemical against dental plaque bacteria on dogs both in vitro and in vivo, and evaluate its ability to interfere in the adherence of bacterial plaque isolates.

\section{Methods}

\section{Bacterial isolates}

Thirty two bacterial isolates were used from ten different genera, which were obtained from dental plaque of mongrel dogs aged between 1 and 2 years, fed with dry feed ad libitum. The number of isolates within each genus was selected following the same percentage that they represented within the total isolates obtained from dogs in the study performed by Pieri [24]: six Streptococcus sp., six Staphylococcus sp., six Enterococcus sp., three Lactobacillus sp., three Leuconostoc sp. two Actinomyces sp., two Bacillus sp., two Lactococcus sp., one Aerococcus sp., and one Haemophilus sp.

\section{Minimum inhibitory concentration (MIC)}

The in vitro assay was performed by adaptation of the agar macrodilution technique [25], which was modified for agar microdilution performed in 96-well microtitre plates. The $\beta$-caryophyllene ( $\geq 98.5 \%$, Sigma-Aldrich, Saint Louis, MO, USA) was incorporated within agar brain heart infusion (BHI), in serial dilutions of logarithmic base 2, in concentrations ranging between 100 and $6.25 \mathrm{mg} / \mathrm{mL}$. As a positive control, chlorhexidine digluconate was used at concentrations between 20 and $0.015 \mathrm{mg} / \mathrm{mL}$, and bacterial growth control was performed with agar BHI without active principle.

The assay was prepared in triplicate for each isolate, filling corresponding wells with $150 \mu \mathrm{L}$ of culture medium with different concentrations of $\beta$-caryophyllene, $150 \mu \mathrm{L}$ with chlorhexidine or $150 \mu \mathrm{L}$ of unsupplemented culture medium. Each well except the last row (non-inoculated as a control of culture medium sterility) was inoculated with $3 \mu \mathrm{L}$ of the adjusted $3 \times 10^{7} \mathrm{UFC} / \mathrm{mL}$ and the plates were incubated for $24 \mathrm{~h}$ at $37^{\circ} \mathrm{C}$. After incubation, the bacterial growth was evidenced by the addition of $50 \mu \mathrm{L}$ resazurin solution at $0.01 \%$ as a colorimetric indicator of oxireduction to characterise cell viability. Interpretation of the results was based on the conversion of resazurin in 
resorufin by microbial metabolism, showing a change of the dye colour from blue to pink when microbial growth occurred. The MIC was based on the lowest concentration of $\beta$-caryophyllene and chlorhexidine in which the dye remained blue, indicating the absence of microbial growth.

\section{Stimulation/inhibition of bacterial adherence}

The quantification of inhibition or stimulation of the bacterial adherence was performed by a microtiter-plate test for quantification biofilm formation according [26], with modifications performed by [27]. Here, 24 bacterial isolates from dog dental plaque of the following genera were tested: Actinomyces sp. (2), Aerococcus sp. (1), Bacillus sp. (1), Enterococcus sp. (6), Haemophilus sp. (1), Lactobacillus sp. (1), Lactococcus sp. (2), Leuconostoc sp. (2), Staphylococcus sp. (3) and Streptococcus sp. (5). From the MIC of $\beta$-caryophyllene against each isolate, six descending serial dilutions of logarithmic base 2 were used (final concentrations). The isolates were reactivated in $\mathrm{BHI}$ incubated at $37{ }^{\circ} \mathrm{C}$ for $24 \mathrm{~h}$ and then adjusted to $0.5 \mathrm{McF}$ arland scale $\left(1.5 \times 10^{8}\right)$. For this, $230 \mu \mathrm{L}$ of each isolate culture was added to the wells of 96 well microtitre plates, and $70 \mu \mathrm{L}$ of test solution was added to assess the final six different concentrations of each isolate, in triplicate. The positive control of bacterial adherence for each isolate consisted of the addition of $230 \mu \mathrm{L}$ of adjusted bacterial culture and $70 \mu \mathrm{L}$ of sterile BHI broth, and the negative control of bacterial adherence was prepared with $300 \mu \mathrm{L}$ of sterile BHI broth. The plates were incubated at $37^{\circ} \mathrm{C}$ for $24 \mathrm{~h}$. After this period, the content was discarded from the plates and these were washed three times with distilled water to remove nonadhered bacteria. Then, $250 \mu \mathrm{L}$ of methanol was added to each well, which was allowed to stand for $15 \mathrm{~min}$. The methanol was discarded, and the plate was dried for 2 min in laminar flow, following staining with $250 \mu \mathrm{L}$ of $1 \%$ crystal violet per well for $10 \mathrm{~min}$. The dye was removed from the plate with tap water and then $250 \mu \mathrm{L}$ of $33 \%$ glacial acetic acid was added. The optical density of each well was measured by a microplate spectrophotometer. With the aid of statistical software Prism 5 (GraphPad Software Inc., La Jolla-CA, USA) the results were analysed by oneway ANOVA comparing treatments to the positive control using the Dunnett's test.

\section{Inhibition of dental plaque formation in dogs}

Here, 18 healthy mongrel dogs, aged between 2 and 8 years old, divided randomly in males and females, were divided into three groups: negative control group (treat solution: tween 80 , butylated hydroxytoluene, sodium benzoate and distilled water); positive control group (negative control solution with $0.12 \%$ chlorhexidine gluconate - commercial concentration of this drug) and test group (negative control solution with $50 \mathrm{mg} / \mathrm{mL}$ of $\beta$-caryophyllene added). The dogs were kept during the experimental period, two by two, in masonry kennels $(1.50 \mathrm{~m} \times 3.00 \mathrm{~m})$.

At the beginning of the experiment, all animals were subjected to a dental cleaning with dental ultrasound (Profi II AS ceramic, Dabi Atlante, Ribeirão Preto, Brazil) and curettage, for the total exclusion of dental plaque, confirmed with a disclosing solution $(0,5 \%$ basic fuchsin solution). The animals in each group were treated with the respective solution twice daily for 15 days. All were fed the same dry food and water ad libitum. At the end of the experimental period, the bacterial dental plaque formed on teeth vestibular surfaces, of canines and pre molars, were observed using $0.5 \%$ basic fuchsin for bacterial identification. These regions were photographed, with digital camera positioned perpendicularly to the imaged surface, distant $30 \mathrm{~cm}$ from the animals, and the images were subjected to analysis in graphic software ImageJ 1.44p (National Institute of Health, Bethesda-MD, USA) to obtain the percentage of total tooth surface area with the presence of dental plaque. Vestibular areas of canine and all premolar teeth of each dog were considered for this analysis. Data were subjected to one-way ANOVA and the parametric Tukey test was used to compare treatment means using the Prism 5 software. For this study, $P<0.05$ was considered significant.

\section{Results and discussion}

\section{Minimum inhibitory concentration}

The results of the MIC test for $\beta$-caryophyllene and chlorhexidine against dental plaque bacterial isolates are shown in Table 1. Overall, $75 \%(24 / 32)$ of the tested isolates were sensitive to $\beta$-caryophyllene at concentrations up to $100 \mathrm{mg} / \mathrm{mL}$. The results of the inhibition of Streptococcus sp. should be highlighted, as streptococci are described as the most important in the initial adhesion of dental plaque in humans [28], and all isolates were inhibited by $\beta$-caryophyllene. This fact suggests that this compound could also be a potential alternative for dental plaque inhibition in humans, after further studies using strains isolated from human samples. The MIC for $50 \%$ (3/6) of isolates of Streptococcus sp. was $\leq$ $6.25 \mathrm{mg} / \mathrm{mL}$, for $33.3 \%(2 / 6)$ was between 6.25 and $12.5 \mathrm{mg} / \mathrm{mL}$, and for $16.7 \%$ (1/6) was between 25 and $50 \mathrm{mg} / \mathrm{mL}$. The isolates showed sensitivity to the tested substance with respect to the MIC profile, as shown in Fig. 2.

Relevant findings of antimicrobial activity by $\beta$ caryophyllene was described by Huang et al. [15], who found that strains of Arabidopsis thaliana flowers that did not have the compound in their chemical composition showed greater growth of bacteria on their stigmas 
Table 1 Minimum inhibitory concentrations of $\beta$-caryophyllene and chlorhexidine against 32 bacterial isolates obtained from dog dental plaque

\begin{tabular}{|c|c|c|c|}
\hline Code & Bacterial genus & $\beta$-caryophyllene & Chlorhexidine \\
\hline HQ717206 & Actinomyces sp. & $25(\mathrm{mg} / \mathrm{mL})$ & $\leq 0.015 \mathrm{mg} / \mathrm{mL}$ \\
\hline HQ717208 & Actinomyces sp. & $12.5(\mathrm{mg} / \mathrm{mL})$ & $\leq 0.015 \mathrm{mg} / \mathrm{mL}$ \\
\hline HQ717237 & Aerococcus sp. & $25(\mathrm{mg} / \mathrm{mL})$ & $\leq 0.015 \mathrm{mg} / \mathrm{mL}$ \\
\hline HQ717211 & Bacillus sp. & $50(r$ & $\leq 0.015 \mathrm{mg} / \mathrm{mL}$ \\
\hline HQ717289 & Bacillus sp. & $>100(\mathrm{mg} / \mathrm{mL})$ & $\leq 0.015 \mathrm{mg} / \mathrm{mL}$ \\
\hline HQ717176 & Enterococcus sp. & $50(\mathrm{mg} / \mathrm{mL})$ & $\leq 0.015 \mathrm{mg} / \mathrm{mL}$ \\
\hline HQ717205 & Enterococcus sp. & $50(\mathrm{mg} / \mathrm{mL})$ & $\leq 0.015 \mathrm{mg} / \mathrm{mL}$ \\
\hline HQ717227 & Enterococcus sp. & $50(\mathrm{mg} / \mathrm{mL})$ & $\leq 0.015 \mathrm{mg} / \mathrm{mL}$ \\
\hline HQ717268 & Enterococcus sp. & 12,5 & $\leq 0.015 \mathrm{mg} / \mathrm{mL}$ \\
\hline HQ717302 & Enterococcus sp. & $12.5(\mathrm{mg} / \mathrm{mL})$ & $\leq 0.015 \mathrm{mg} / \mathrm{mL}$ \\
\hline HQ717350 & Enterococcus sp. & $25(\mathrm{mg} / \mathrm{mL})$ & $\leq 0.015 \mathrm{mg} / \mathrm{mL}$ \\
\hline HQ717319 & Haemophilus sp. & $100(\mathrm{mg} / \mathrm{mL})$ & $\leq 0.015 \mathrm{mg} / \mathrm{mL}$ \\
\hline HQ717266 & Lacto & 12.5 & $\leq 0.0$ \\
\hline HQ717270 & Lactobacillus sp. & $50(\mathrm{mg} / \mathrm{mL})$ & $\leq 0.015 \mathrm{mg} / \mathrm{mL}$ \\
\hline HQ717278 & Lactc & 50 & $/ \mathrm{mL}$ \\
\hline HQ717330 & Lactococcus sp. & $6.25(\mathrm{mg} / \mathrm{mL})$ & $\leq 0.015 \mathrm{mg} / \mathrm{mL}$ \\
\hline HQ717335 & Lactococcus sp. & $6.25(\mathrm{mg} / \mathrm{mL})$ & $\leq 0.015 \mathrm{mg} / \mathrm{mL}$ \\
\hline HQ717296 & Leuconostoc sp. & $50(\mathrm{mg} / \mathrm{mL})$ & $\leq 0.015 \mathrm{mg} / \mathrm{mL}$ \\
\hline HQ717308 & Leuconostoc sp. & $>100(\mathrm{mg} / \mathrm{mL})$ & $\leq 0.015 \mathrm{mg} / \mathrm{mL}$ \\
\hline HQ717331 & Leuconostoc sp. & $>100(\mathrm{mg} / \mathrm{mL})$ & $\leq 0.015 \mathrm{mg} / \mathrm{mL}$ \\
\hline HQ717182 & Staphylococcus sp. & $25(\mathrm{mg} / \mathrm{mL})$ & $\leq 0.015 \mathrm{mg} / \mathrm{mL}$ \\
\hline HQ717223 & Staphylococcus sp. & $>100(\mathrm{mg} / \mathrm{mL})$ & $\leq 0.015 \mathrm{mg} / \mathrm{mL}$ \\
\hline HQ717224 & Staphylococcus sp. & $>100(\mathrm{mg} / \mathrm{mL})$ & $\leq 0.015 \mathrm{mg} / \mathrm{mL}$ \\
\hline HQ717232 & Staphylococcus sp. & $>100(\mathrm{mg} / \mathrm{mL})$ & $\leq 0.015 \mathrm{mg} / \mathrm{mL}$ \\
\hline HQ717306 & Staphylococcussp. & $>100(\mathrm{mg} / \mathrm{mL})$ & $\leq 0.015 \mathrm{mg} / \mathrm{mL}$ \\
\hline HQ717309 & Staphylococcus sp. & $>100(\mathrm{mg} / \mathrm{mL})$ & $\leq 0.015 \mathrm{mg} / \mathrm{mL}$ \\
\hline HQ717228 & Streptococcus sp. & $50(\mathrm{mg} / \mathrm{mL})$ & $\leq 0.015 \mathrm{mg} / \mathrm{mL}$ \\
\hline HQ717229 & Streptococcus sp. & $6.25(\mathrm{mg} / \mathrm{mL})$ & $\leq 0.015 \mathrm{mg} / \mathrm{mL}$ \\
\hline 242 & Strepto & $6.25(\mathrm{mg} / \mathrm{mL})$ & $\leq 0$ \\
\hline HQ717243 & Streptococcus sp. & $6.25(\mathrm{mg} / \mathrm{mL})$ & $\leq 0.015 \mathrm{mg} / \mathrm{mL}$ \\
\hline HQ717249 & Streptococcus sp. & $12.5(\mathrm{mg} / \mathrm{mL})$ & $\leq 0.015 \mathrm{mg} / \mathrm{mL}$ \\
\hline HQ717305 & Streptococcus sp. & $12.5(\mathrm{mg} / \mathrm{mL})$ & $\leq 0.015 \mathrm{mg} / \mathrm{mL}$ \\
\hline
\end{tabular}

Codes presented are the respective numbers of deposit of the 16S rRNA sequences of each isolate in GenBank

compared with the wild type that showed $\beta$-caryophyllene in its composition.

In vitro studies showed natural products that are present as the major compound $\beta$-caryophyllene, with significant antimicrobial activity, suggesting that the substance possibly participated in this activity. Da Costa et al. [20] studied the antibacterial activity of extract of Lantana camara, composed $31.5 \%$ by $\beta$-caryophyllene. The results showed significant antimicrobial activity, especially against Proteus vulgaris (ATCC 13315) and Escherichia coli

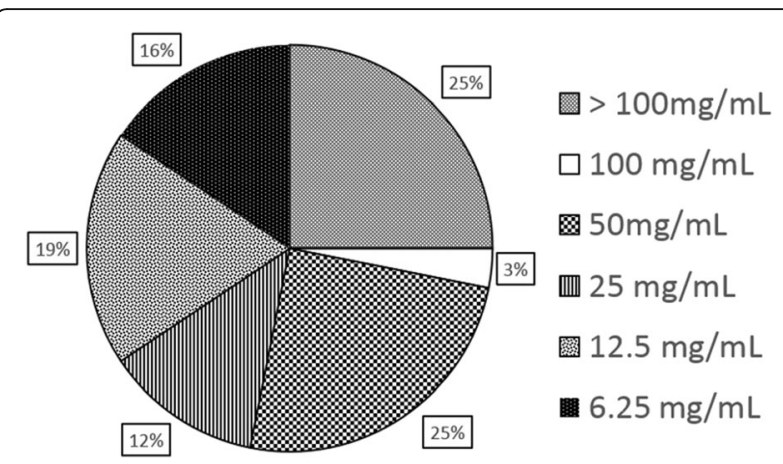

Fig. 2 Distribution of sensitivity of 32 dental plaque bacterial isolates obtained from dogs classified based on minimum inhibitory concentrations of $\beta$-caryophyllene

(ATCC 25922). Maia et al. [21] presented the antibacterial activity of the essential oils of Vernonia remotiflora and $V$. braziliana, both with more than $40 \% \beta$-caryophyllene, with a broad spectrum of antibacterial activity, inhibiting the growth of several tested Gram-negative and Grampositive bacteria, including S. aureus and Pseudomonas aeruginosa.

Ghosh et al. [29] evaluated the activity of essential oils of Alpinia nigra (47.7 to $49 \%$ of $\beta$-caryophyllene) against Gram-positive and Gram-negative bacteria. The lowest MIC was found against Yersinia enterocolitica $(1.56 \mu \mathrm{L} / \mathrm{mL})$. In the present study, Staphylococcus isolates had relatively high MICs (one was $25 \mathrm{mg} / \mathrm{mL}$ and five were resistant up to $100 \mathrm{mg} / \mathrm{mL}$ ) compared to the isolate of $S$. aureus in the study of Ghosh et al. [29], which showed MICs ranging between 3.12 and $6.25 \mu \mathrm{L} / \mathrm{mL}$ depending on the essential oil of $A$. nigra analysed. This difference in susceptibility of bacteria of the same genus may have occurred by synergistic action of $\beta$-caryophyllene with other substances present in the tested oil [30], or due to the intrinsic resistance of wild isolates of the present study to this phytotherapic was higher when compared to that strain tested by Ghosh et al. [29].

Souza et al. [30] investigated the antibacterial activity of $\beta$-caryophyllene against cariogenic bacteria in humans, Streptococcus mutans, S. mitis, S. sobrinus, S. sanguinis, and Lactobacillus casei, and showed MICs of 200, 150, 180, 200 and $150 \mu \mathrm{g} / \mathrm{mL}$, respectively. These concentrations were lower than those found in the present study, indicating a higher susceptibility of bacteria in human dental plaque than those isolated from dogs, making it an even more promising compound for use in dental therapy in humans.

Corroborating this promising employment in human dental therapy, Mussi [31] conducted tests of MIC with one oil from Copaifera officinalis (with $50.78 \% \beta$ caryophyllene) against bacteria that cause severe periodontal disease in humans: Fusobacterium nucleatum and Porphyromonas gingivalis. The solution of copaiba was active against $F$. nucleatum from the concentration 
$100 \mu \mathrm{L} / \mathrm{mL}$, while the MIC against $P$. gingivalis was $2 \mu \mathrm{L} / \mathrm{mL}$. However, for $P$. gingivalis the nature of the antimicrobial activity was bacteriostatic at all concentrations tested, while for $F$. nucleatum the MIC was also the minimum bactericidal concentration $(\mathrm{MBC})$.

\section{Stimulation/inhibition of bacterial adherence}

Table 2 lists the isolates that showed some inhibition or stimulation in its adherence capability by some subinhibitory concentration of $\beta$-caryophyllene, with statistical significance $(P<0.05)$ when compared with the control. Within the 24 isolates tested, eight (33.33\%) showed an altered ability to form biofilms enough to be detected by statistical analysis. An isolate of Lactococcus sp. suffered inhibition of its adherence by concentrations of $1.56 \mathrm{mg} / \mathrm{mL} \%$ and $3.12 \mathrm{mg} / \mathrm{mL}(P<0.05)$, while concerning the challenge with $0.19 \mathrm{mg} / \mathrm{mL}$ of $\beta$ caryophyllene, the activity was the stimulus to the adherence of the same isolate $(P<0.05)$. One Streptococcus sp. and one Bacillus sp. presented similar results, being inhibited to adhere by some concentrations and stimulated by other one (Table 2).

It can be seen in Table 2 that the eight isolates that showed statistical differences in the adherence to microtitre plate orifices were from six different genera, Streptococcus sp. (1/5), Haemophilus sp. (1/1), Aerococcus sp. (1/1), Lactococcus sp. (1/2), Bacillus sp. (1/1) and Enterococcus sp. (3/ 6). As more than one isolate of each genus were tested for Streptococcus, Enterococcus and Lactococcus, it can be stated, at least to these genera, that the susceptibility to

Table 2 Stimulation/Inhibition of bacterial adherence in microtiter plates by subinhibitory concentrations of $\beta$-caryophyllene

\begin{tabular}{|c|c|c|c|c|c|}
\hline Code & Bacterial genus & Subinhibitory concentration $(\mathrm{mg} / \mathrm{mL})$ & Action on bacterial adherence & Control OD mean (SE) & Treated OD mean (SE, \\
\hline \multirow[t]{4}{*}{ HQ717249 } & Streptococcus sp. & 6.25 & Inhibition & $0.306(0.018)$ & $0.093(0.011)$ \\
\hline & & 3.12 & Inhibition & $0.306(0.018)$ & $0.106(0.009)$ \\
\hline & & 1.56 & Inhibition & $0.306(0.018)$ & $0.117(0.013)$ \\
\hline & & 0.78 & Stimulus & $0.306(0.018)$ & $0.578(0.021)$ \\
\hline \multirow[t]{4}{*}{ HQ717319 } & Haemophilus sp. & 50.00 & Inhibition & $0.125(0.001)$ & $0.076(0.001)$ \\
\hline & & 25.00 & Inhibition & $0.125(0.001)$ & $0.071(0.001)$ \\
\hline & & 12.50 & Inhibition & $0.125(0.001)$ & $0.087(0.004)$ \\
\hline & & 6.25 & Inhibition & $0.125(0.001)$ & $0.089(0.003)$ \\
\hline \multirow[t]{3}{*}{ HQ717330 } & Lactococcus sp. & 3.12 & Inhibition & $1.072(0.050)$ & $0.203(0.065)$ \\
\hline & & 1.56 & Inhibition & $1.072(0.050)$ & $0.458(0.080)$ \\
\hline & & 0.19 & Stimulus & $1.072(0.050)$ & $1.590(0.157)$ \\
\hline HQ717350 & Enterococcus sp. & 12.50 & Inhibition & $0.209(0.005)$ & $0.076(0.001)$ \\
\hline \multirow[t]{4}{*}{ HQ717176 } & Enterococcus sp. & 25.00 & Inhibition & $0.114(0.003)$ & $0.075(0.001)$ \\
\hline & & 12.50 & Inhibition & $0.114(0.003)$ & $0.073(0.005)$ \\
\hline & & 6.25 & Inhibition & $0.114(0.003)$ & $0.065(0.001)$ \\
\hline & & 1.56 & Inhibition & $0.114(0.003)$ & $0.073(0.003)$ \\
\hline \multirow[t]{5}{*}{ HQ717227 } & Enterococcus sp. & 25.00 & Inhibition & $0.676(0.061)$ & $0.094(0.017)$ \\
\hline & & 12.50 & Inhibition & $0.676(0.061)$ & $0.075(0.007)$ \\
\hline & & 6.25 & Inhibition & $0.676(0.061)$ & $0.068(0,001)$ \\
\hline & & 3.12 & Inhibition & $0.676(0.061)$ & $0.083(0.005)$ \\
\hline & & 1.56 & Inhibition & $0.676(0.061)$ & $0.122(0.017)$ \\
\hline \multirow[t]{5}{*}{ HQ717211 } & Bacillus sp. & 25.00 & Inhibition & $0.398(0.008)$ & $0.088(0.013)$ \\
\hline & & 12.50 & Inhibition & $0.398(0.008)$ & $0.077(0.009)$ \\
\hline & & 6.25 & Inhibition & $0.398(0.008)$ & $0.112(0.031)$ \\
\hline & & 3.12 & Inhibition & $0.398(0.008)$ & $0.168(0.019)$ \\
\hline & & 1.56 & Stimulus & $0.398(0.008)$ & $0.517(0.055)$ \\
\hline \multirow[t]{2}{*}{ HQ717237 } & Aerococcus sp. & 12.50 & Inhibition & $0.119(0.005)$ & $0.082(0.002)$ \\
\hline & & 1.56 & Inhibition & $0.119(0.005)$ & $0.071(0.001)$ \\
\hline
\end{tabular}

Codes presented are the respective numbers of deposit of the $16 \mathrm{~S}$ rRNA sequences of each isolate in GenBank. Means ( \pm SE) of optical density are related to measurement under $550 \mathrm{~nm}$ absorbance $\left(\mathrm{OD}_{550}\right)$. All of the presented results showed a significant difference between the test treatment and the control of isolates natural adherence without any treatment $(P<0.05)$ 
changes in adherence capability is characterised in strain level. This fact was presented before [6], with different $E$. coli strains presenting different interference levels in biofilm formation when challenged by enrofloxacin.

Pieri et al. [3] studied the effects of Copaifera officinalis oil, which is described in the work of Mussi [31] as containing more than $50 \% \beta$-caryophyllene, on the adhesion of the bacteria Streptococcus mutans, the main involved in the initial formation of dental plaque in humans. Analysis of the inhibition of adherence assays showed superiority of the test group compared with the negative control and positive control with chlorhexidine. In the present study, an isolate of the same genus had its adhesiveness inhibited by sub-inhibitory concentrations of $\beta$-caryophyllene between 1.56 and $6.25 \mathrm{mg} / \mathrm{mL}$ and stimulated to adhere at $0.78 \mathrm{mg} / \mathrm{mL}$. However, other isolates of Streptococcus sp. were also tested, but presented no significant change in their ability to adhere, which supports the individuality of each strain with respect to variation in adherence capability by the tested compound.

Mussi [31] conducted tests to evaluate the co-aggregation and self-aggregation (processes related to microbial adherence in dental plaque of the advanced periodontal disease) by the periodontal pathogens Fusobacterium nucleatum and Porphyromonas gingivalis challenged with subinhibitory concentrations of Copaifera officinalis oil, composed of $50.78 \%$ of $\beta$-caryophyllene. When F. nucleatum was treated, a reduction in the self-aggregation process was observed when compared to untreated cells. $P$. gingivalis was not able to self-aggregate under the tested conditions. The solution of $C$. officinalis tested also inhibited co-aggregation between these two bacterial species, which is an important event in the progression of periodontal disease in humans, again demonstrating the great employment potential of $\beta$-caryophyllene in human dentistry.

It's significant to highlight that in the present work we used aerobes as target strains. This kind of bacteria are not involved in the etiology of periodontal disease, but are critical to early stages in development of dental biofilm, creating from its installation, a favorable environment for the development of anaerobes, which actively participate in the development of the disease [32]. Thus the results of this study point to a relevant activity of $\beta$ caryophyllene on aerobes, presenting relevant potential in use to combat dental plaque formation in its early stages. The use in combating plaque formation could promote a prevention of the disease through a reduction of the environmental conditions that promote the development of periodontal pathogens in the biofilm. However, further studies should be conducted evaluating the direct antimicrobial effect on the anaerobic periodontal pathogens, which may point, beyond the preventive potential, the possibility of use $\beta$-caryophyllene in the treatment of disease.

\section{Inhibition of dental plaque formation in dogs}

The results obtained in the in vivo assay are shown in Fig. 3. The results indicated the coverage area of teeth with plaque (mean $\pm \mathrm{SE}$ ) to be $23.3 \pm 2.6 \%$ for $\beta$ caryophyllene test solution, $37.5 \pm 3.7 \%$ for the positive control solution and $65.56 \pm 2.5 \%$ coverage for the negative control solution. The test and positive control groups were statistically lower on average than the negative control $(P<0.001)$ dental plaque presence and were different $(P<0.05)$ with regard to inhibiting dental plaque formation, with better results for $\beta$-caryophyllene. These results indicate that $\beta$-caryophyllene is a potential natural alternative to the use of chlorhexidine in reducing dental plaque in dogs, resulting in a patent application of pharmaceutical formulations containing $\beta$-caryophyllene for use in the treatment and prophylaxis of canine periodontal disease [33].

A similar assay was performed by Pieri et al. [3] using one Copaifera officinalis oil with good results in the inhibition of dental plaque formation when compared to negative control. In their work, chlorhexidine reduced the formation of dental plaque to a final coverage of $28.5 \%$ of the analysed area of teeth, while in the present work, the group treated with the same substance presented $37.5 \%$ plaque coverage. This difference could be happen due to different susceptibility to chlorhexidine of the dogs' dental microbiota in the different works, or the different treatment periods, which was 8 days in the previous work and 15 days in the current study. However, it is interesting to highlight that the level of final plaque coverage of groups treated with $C$. officinalis [3] and $\beta$ caryophyllene (present work) were very close. As this oil is frequently associated with high concentrations of $\beta$ -

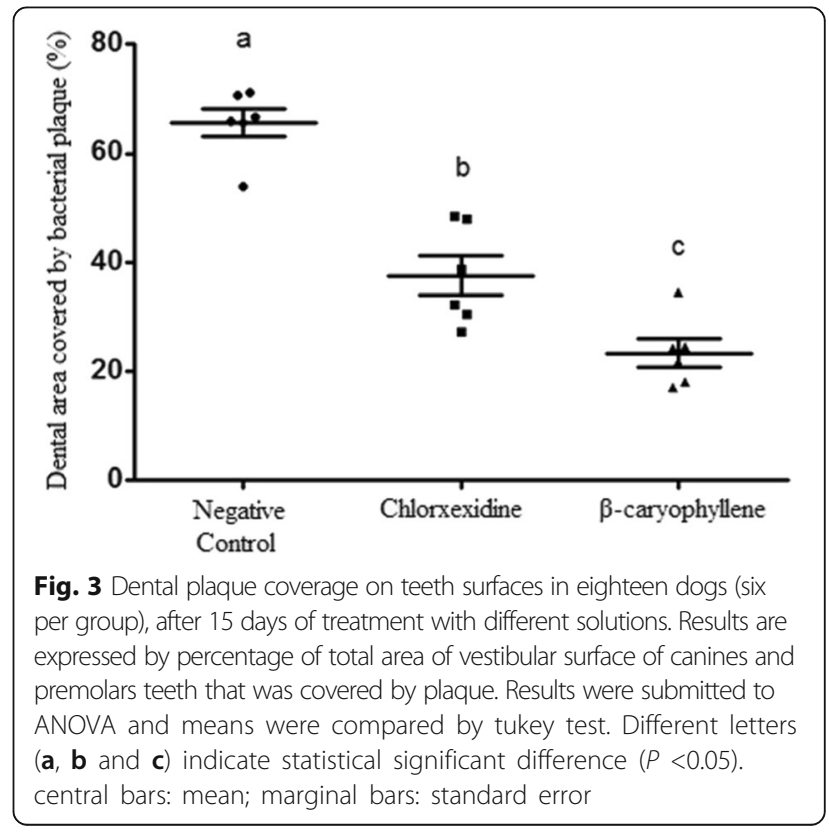


caryophyllene, the activity of $C$. officinalis oil used in that work against dogs' dental plaque [3] could be due to the presence of this compound.

\section{Conclusions}

With the data obtained it can be concluded that $\beta$ caryophyllene has antimicrobial activity against dental plaque bacteria of dogs, and this activity is reflected in the reduction of this on the teeth surfaces of dogs. Therefore, after other clinical trials with a larger number of dogs and different breeds, $\beta$-caryophyllene could be indicated as an alternative to the use of chlorhexidine in the treatment and prophylaxis of periodontal disease in these animals.

\section{Abbreviations}

ANOVA: Analysis of variance; ATCC: American type culture collection; BHI: Brain heart infusion; CEUA: Ethics Committee on Animal Use; COBEA: Brazilian College for Animal Experimentation; MBC: Minimum bactericidal concentration; MIC: Minimum inhibitory concentration; SE: Standard error

\section{Acknowledgements}

The authors thank the Fundação de Amparo à Pesquisa do Estado de Minas Gerais (FAPEMIG), Coordenação de Aperfeiçoamento de Pessoal de Nível Superior (CAPES) and Conselho Nacional de Desenvolvimento Científico e Tecnológico (CNPq) for financial support. Our acknowledgements also go to the Veterinarians Camila Corsini, Elisa Bourguignon, Letícia Correa, Lívia Alvarenga, Clara Ochoa and Raul Dornas for conducting the initial dental cleaning in vivo and Natalia Fernandes and Gustavo Pereira for the care of the animals during the experimental period.

\section{Availability of data and materials}

The data set supporting the results of this article is included within the article.

\section{Authors' contribution}

FAP contributed to conception and design of the study, acquisition, analysis and interpretation of data. MCCS contributed to acquisition, analysis and interpretation of data. LLRV, MLRV and PGP contributed to acquisition of data. FSV, APBB and VFVJ contributed to analysis and interpretation of data. MASM contributed to conception and design of the study, analysis and interpretation of data. All authors revised the manuscript critically for important intellectual content, have given final approval of the version to be submitted and are accountable for all aspects of the work in ensuring that questions related to the accuracy or integrity of any part of the work are appropriately investigated and resolved.

\section{Authors' information}

FAP is graduated in Veterinary Medicine and PhD in Veterinary Medicine from the Universidade Federal de Viçosa (UFV), Brazil, working with phytopharmacology applied to Veterinary Dentistry Microbiology. Is currently professor of Microbiology to the graduation courses of Dentistry, Pharmacy and Medicine at Universidade Federal de Juiz de Fora (UFJF), Brazil. MCCS, LLRV and MLRV are graduated in Veterinary Medicine from UFV; PGP is graduated in Veterinary Medicine from Universidade Federal do Espírito Santo (UFES), Brazil. FSV is graduated in Pharmacy and PhD in Biotechnology from the Universidade Federal do Amazonas (UFAM); APBB is Graduated in Veterinary Medicine from UFV and PhD in animal science from Universidade Federal de Minas Gerais (UFMG). She is currently professor of animal surgery in veterinary college at UFV. VFVJ is graduated in chemistry and $\mathrm{PhD}$ in the same area from Universidade Federal do Rio de Janeiro (UFRJ). He currently is professor in Chemistry college at UFAM, working with organic chemistry and natural products. MASM is graduated in veterinary medicine from UFV and PhD in Agricultural Microbiology from UFV. He is currently professor of veterinary microbiology and bacterial diseases of veterinary college at UFV.

\section{Competing interests}

The authors declare that they have no competing interests.

\section{Ethics approval and consent to participate}

The experiment followed the guidelines established by the Ethics Committee on Animal Use (CEUA) of the Federal University of Viçosa that follows the guidelines of Brazilian College of Animal Experimentation (COBEA), and was approved under protocol number 18/2010. Bacterial isolates were isolated from dogs between 1 and 2 years, that were treated in Veterinary Hospital of the Universidade Federal de Viçosa. All dogs used in the in vivo test were part of the kennel of Veterinary Department of the Universidade Federal de Viçosa and were all castrated and given to private owners after the trial period.

\section{Author details}

${ }^{1}$ Departamento de Ciências Básicas da Vida, Universidade Federal de Juiz de Fora, Rua Israel Pinheiro, 2000, Bairro Universitário, CEP: 35020-220 Governador Valadares, Minas Gerais, Brasil. ²Departamento de Veterinária, Universidade Federal de Viçosa, Av. P.H. Rolfs, s/n, Câmpus UFV, CEP: 36570-000 Viçosa, Minas Gerais, Brasil. ${ }^{3}$ Instituto de Ciências Exatas, Universidade Federal do Amazonas, Av. Rodrigo Otávio, 6200, Coroado, CEP: 69.080-005 Manaus, Amazonas, Brasil.

Received: 26 February 2015 Accepted: 16 September 2016

Published online: 01 October 2016

References

1. Kyllar M, Witter K. Prevalence of dental disorders in pet dogs. Vet Med. 2005; 50(11):496-505

2. Niemiec BA. Periodontal disease. Top Companion Anim Med. 2008;23(2):72-80.

3. Pieri FA, Mussi MC, Fiorini JE, Schneedorf JM. Clinical and microbiological effects of copaiba oil (Copaifera officinalis) on dental plaque forming bacteria in dogs]. Arquivo Brasileiro de Medicina Veterinaria e Zootecnia. 2010;62(3):578-85.

4. Hoffman LR, D'Argenio DA, MacCoss MJ, Zhang Z, Jones RA, Miller SI. Aminoglycoside antibiotics induce bacterial biofilm formation. Nature. 2005; 436(7054):1171-5.

5. Melchior MB, Vaarkamp H, Fink-Gremmels J. Biofilms: a role in recurrent mastitis infections? Vet J. 2006;171(3):398-407.

6. Costa JCM, Espeschit IDF, Pieri FA, Benjamin LDA, Moreira MAS. Increased production of biofilms by Escherichia coli in the presence of enrofloxacin. Vet Microbiol. 2012;160(3-4):488-90.

7. Hennet P. Effectiveness of a dental gel to reduce plaque in beagle dogs. J Vet Dent. 2002;19(1):11-4.

8. Dantas E, Xavier C, Segundo G, Paiva M, Lima K. Dental staining by chlorhexidine: case report. Odontologia Clin Cientif. 2007;6:175-8.

9. Pieri FA, Silva VO, Vargas FS, Veiga Junior VF, Moreira MAS. Antimicrobial activity of Copaifera langsdorffii oil and evaluation of its most bioactive fraction against bacteria of dog's dental plaque. Pakistan Vet J. 2014;34(2):165-9.

10. CAS. Chemical Book. Columbus: Chemical Abstract Service; 2010.

11. Ghelardini C, Galeotti N, Di Cesare ML, Mazzanti G, Bartolini A. Local anaesthetic activity of $\beta$-caryophyllene. Farmaco. 2001;56(5-7):387-9.

12. Abbas MA, Taha MO, Zihlif MA, Disi AM. $\beta$-Caryophyllene causes regression of endometrial implants in a rat model of endometriosis without affecting fertility. Eur J Pharmacol. 2013;702(1-3):12-9.

13. Cho JY, Chang HJ, Lee SK, Kim HJ, Hwang JK, Chun HS. Amelioration of dextran sulfate sodium-induced colitis in mice by oral administration of $\beta$ caryophyllene, a sesquiterpene. Life Sci. 2007;80(10):932-9.

14. Leonhardt V, Leal-Cardoso JH, Lahlou S, Albuquerque AAC, Porto RS, Celedônio NR, et al. Antispasmodic effects of essential oil of Pterodon polygalaeflorus and its main constituent $\beta$-caryophyllene on rat isolated ileum. Fundam Clin Pharmacol. 2010;24(6):749-58.

15. Huang M, Sanchez-Moreiras AM, Abel C, Sohrabi R, Lee S, Gershenzon J, et al. The major volatile organic compound emitted from Arabidopsis thaliana flowers, the sesquiterpene (E)- $\beta$-caryophyllene, is a defense against a bacterial pathogen. New Phytologist. 2012;193(4):997-1008.

16. Galdino PM, Nascimento MVM, Florentino IF, Lino RC, Fajemiroye JO, Chaibub BA, et al. The anxiolytic-like effect of an essential oil derived from Spiranthera odoratissima A. St. Hil. leaves and its major component, $\beta$ caryophyllene, in male mice. Prog Neuropsychopharmacol Biol Psychiatry. 2012;38(2):276-84

17. Chang HJ, Kim JM, Lee JC, Kim WK, Chun HS. Protective effect of $\beta$ caryophyllene, a natural bicyclic sesquiterpene, against cerebral ischemic injury. J Med Food. 2013;16(6):471-80. 
18. Rasooli I, Mirmostafa SA. Bacterial susceptibility to and chemical composition of essential oils from Thymus kotschyanus and Thymus persicus. J Agric Food Chem. 2003;51 (8):2200-5. doi:10.1021/jf0261755.

19. Chaibub BA, Oliveira TB, Fiuza TS, Bara MTF, Tresvenzol LMF, Paula JR. Chemical composition of the essential oil and evaluation of the antimicrobial activity of essential oil, crude ethanol extract and fractions of Spiranthera odoratissima A. St.-Hil. Leaves. Revista Brasileira de Plantas Medicinais. 2013;15(2):225-9.

20. Da Costa JGM, De Sousa EO, Rodrigues FFG, De Lima SG, Braz-Filho R. Chemical composition, evaluation of antibacterial activity and toxicity of the essential oils from Lantana camara L. and Lantana sp. Braz J Pharmacog. 2009;19(3):710-4.

21. Maia AIV, Torres MCM, Pessoa ODL, De Menezes JESA, Costa SMO, Nogueira VLR, et al. Volatile leaf oils of Vernonia Brasiliana and Vernonia remotiflora: chemical composition and biological activity. Quimica Nova. 2010;33(3):584-6.

22. Machado RRP, Jardim DF, Souza AR, Scio E, Fabri RL, Carpanez AG, et al. The effect of essential oil of Syzygium cumini on the development of granulomatous inflammation in mice. Braz J Pharmacog. 2013;23(3):488-96.

23. Bitu V, Botelho MA, da Costa JGM, Rodrigues FFG, Veras HNH, Martins KT, et al. Phythochemical screening and antimicrobial activity phytochemical of essential oil of Lippia gracillis. Revista Brasileira de Farmacognosia. 2012; 22(1):69-75. doi:10.1590/50102-695X2011005000173.

24. Pieri FA. Atividade antimicrobiana do óleo de copaíba (Copaifera langsdorffii) e seus constituintes, e avaliação do bioproduto obtido na inibição de bactérias da placa dental de cães. Viçosa-MG: Universidade Federal de Viçosa; 2012.

25. CLSI. Methods for Dilution Antimicrobial Susceptibility Tests for Bacteria That Grow Aerobically; Approved Standard. 9th edition. CLSI document M07-A9. 9th ed. Waine: Clinical and Laboratory Standards Institute; 2012.

26. Stepanović S, Vuković D, Dakić I, Savić B, Švabić-Vlahović M. A modified microtiter-plate test for quantification of staphylococcal biofilm formation. J Microbiol Methods. 2000;40(2):175-9.

27. Costa JCM, Espeschit IF, Pieri FA, Carvalho IA, Moreira MAS. Sensitivity profile of planktonic and sessile cells of escherichia coli to antimicrobial used in the treatment of bovine mastitis. Arquivo Brasileiro de Medicina Veterinaria e Zootecnia. 2014;66(1):129-36.

28. Katsura H, Tsukiyama RI, Suzuki A, Kobayashi M. In vitro antimicrobial activities of bakuchiol against oral microorganisms. Antimicrob Agents Chemother. 2001:45(11):3009-13.

29. Ghosh S, Ozek T, Tabanca N, Ali A, ur Rehman J, Khan IA, et al. Chemical composition and bioactivity studies of Alpinia nigra essential oils. Ind Crops Prod. 2014;53:111-9.

30. Souza AB, Martins CHG, Souza MGM, Furtado NAJC, Heleno VCG, De Sousa JPB, et al. Antimicrobial activity of terpenoids from Copaifera langsdorffii Desf. against cariogenic bacteria. Phytother Res. 2011;25(2):215-20.

31. Mussi MCM. Análise da atividade antimicrobiana dos óleos de copaíba (Copaifera officinalis) e de melaleuca (Melaleuca alternifólia) sobre Fusobacterium nucleatum e Porphyromonas gingivalis: determinação das concentrações inibitórias e bactericidas mínimas e efeito de concentrações subinibitórias sobre a agregação. Bauru-SP: Universidade de São Paulo; 2011.

32. Davis IJ, Wallis C, Deusch O, Colyer A, Millella L, Loman N, et al. A crosssectional survey of bacterial species in plaque from client owned dogs with healthy gingiva, gingivitis or mild periodontitis. PLoS One. 2013;8(12), e83158.

33. Moreira MAS, Pieri FA, Silva VO, Veiga Junior VF, Vargas FS, Inventors. Formulação farmacêutica contendo beta-cariofileno e uso no tratamento e profilaxia da doença periodontal canina. Rio de Janeiro: Instituto Nacional da Propriedade Intelectual; 2013.

\section{Submit your next manuscript to BioMed Central and we will help you at every step:}

- We accept pre-submission inquiries

- Our selector tool helps you to find the most relevant journal

- We provide round the clock customer support

- Convenient online submission

- Thorough peer review

- Inclusion in PubMed and all major indexing services

- Maximum visibility for your research

Submit your manuscript at www.biomedcentral.com/submit
Biomed Central 